University of Nebraska - Lincoln

DigitalCommons@University of Nebraska - Lincoln

\title{
Organic carbon dynamics and soil stability in five semiarid agroecosystems
}

\author{
Lisa M. Fultz \\ Texas Tech University, lisamfultz@gmail.com \\ Jennifer Moore-Kucera \\ Texas Tech University, jennifer.moore-kucera@ttu.edu \\ Ted M. Zobeck \\ USDA-ARS, ted.zobeck@ars.usda.gov \\ Veronica Acosta-Martinez \\ USDA-ARS, veronica.acosta-martinez@ars.usda.gov
}

David B. Wester

Texas A\&M University, Wildlife Sciences \& Caesar Kleberg Wildlife Research Institute, david.wester@tamuk.edu

See next page for additional authors

Follow this and additional works at: https://digitalcommons.unl.edu/usdaarsfacpub

Fultz, Lisa M.; Moore-Kucera, Jennifer; Zobeck, Ted M.; Acosta-Martinez, Veronica; Wester, David B.; and Allen, Vivien G., "Organic carbon dynamics and soil stability in five semiarid agroecosystems" (2013).

Publications from USDA-ARS / UNL Faculty. 1417.

https://digitalcommons.unl.edu/usdaarsfacpub/1417

This Article is brought to you for free and open access by the U.S. Department of Agriculture: Agricultural Research Service, Lincoln, Nebraska at DigitalCommons@University of Nebraska - Lincoln. It has been accepted for inclusion in Publications from USDA-ARS / UNL Faculty by an authorized administrator of DigitalCommons@University of Nebraska - Lincoln. 


\section{Authors}

Lisa M. Fultz, Jennifer Moore-Kucera, Ted M. Zobeck, Veronica Acosta-Martinez, David B. Wester, and Vivien G. Allen 


\title{
Organic carbon dynamics and soil stability in five semiarid agroecosystems
}

\author{
Lisa M. Fultz ${ }^{\mathrm{a}}$, Jennifer Moore-Kucera ${ }^{\mathrm{a}, *}$, Ted M. Zobeck ${ }^{\mathrm{b}}$, Veronica Acosta-Martínez ${ }^{\mathrm{b}}$, \\ David B. Wester ${ }^{c}$, Vivien G. Allen ${ }^{\mathrm{a}}$ \\ a Department of Plant and Soil Science, Texas Tech University, Box 42122, Lubbock, TX 79409, USA \\ b USDA-ARS, Cropping Systems Research Laboratory, 3810 4th Street, Lubbock, TX 79415, USA \\ ' Department of Animal, Rangeland, and Wildlife Sciences \& Caesar Kleberg Wildlife Research Institute, Texas AEM University, MSC 228, Kingsville, TX \\ 78363, USA
}

\section{A R T I C L E I N F O}

\section{Article history:}

Received 12 May 2013

Received in revised form 21 September 2013

Accepted 7 October 2013

Available online 12 November 2013

\section{Keywords:}

Soil organic carbon

Aggregates

Integrated crop-livestock

Carbon

Sequestration

Intra-aggregate

\begin{abstract}
A B S T R A C T
Interest in integrated crop-livestock agroecosystems (ICL) has increased due to their versatility in management options, potential to offset increasing levels of atmospheric $C$ and enhanced agronomic and ecosystem sustainability. Identifying agroecosystems that have the greatest potential for $\mathrm{C}$ sequestration requires an understanding of soil organic $C$ distribution within aggregate fractions. Six soil aggregate $C$ pools were physically isolated to evaluate the $C$ sequestration potential of three ICLs and two continuous cotton (CTN) agroecosystems in the Texas High Plains. The proportions of the water stable aggregate fractions were used to calculate mean weight diameter, an indicator of soil stability. The first ICL (FRG_CTN) included paddocks of dryland perennial native grasses, a foxtail millet-cotton (Setaria italica [L.] P. Beauv. and FiberMax 9058F, respectively) rotation, and WW B-Dahl - Old World Bluestem [bluestem; Bothriochloa bladhii (Retz) S.T. Blake] under deficit irrigation (replacement of approximately $30 \%$ evapotranspiration). The second ICL (OWB_BER) included paddocks of deficit irrigated bermudagrass [bermuda; Cynodon dactylon (L.) Pers.] and bluestem and the third ICL (FRG_RC) included paddocks of irrigated bluestem and row crop production. Soil samples $(0-5$ and 5-20 cm) were collected in July 2010 . In general, ICLs increased water stable macroaggregates providing a physical protective shell for SOC and increasing $C$ sequestration potential. A strong correlation between SOC and mean weight diameter identified a critical SOC level of $5.5 \mathrm{Mg} \mathrm{ha}^{-1}$ for the greatest increases in mean weight diameter. Of the five agroecosystems evaluated, FRG_RC and OWB_BER ranked the highest in terms of mean weight diameter ( $130 \%$ larger), whole SOC (up to $45 \%$ more), and intra-aggregate microaggregate SOC (157\% greater) relative to CTN production. Increased stability and reduced exposure of intra-aggregate fractions resulted in relatively greater intra-aggregate microaggregate SOC under perennial vegetation. The potential to serve as significant SOC accumulators may aid in offsetting increasing atmospheric $C$ levels, and while specific to these semiarid soils, the identified critical SOC level can act as a target for producers to minimize and ultimately reverse soil degradation.
\end{abstract}

(C) 2013 Elsevier B.V. All rights reserved.

\section{Introduction}

Agricultural production must balance the goals of meeting the needs of a growing population in the face of a changing climate and the decline of energy and water resources (Blanco-Canqui and

Abbreviations: C, carbon; SOC, soil organic carbon; CTN, continuous cotton; ICL, integrated crop-livestock agroecosystem; SOM, soil organic matter; POM, particulate organic matter.

* Corresponding author. Tel.: +1 806742 2838x236; fax: +1 8067420775 .

E-mail addresses: lisamfultz@gmail.com (L.M. Fultz), jennifer.moore-kucera@ttu.edu (J. Moore-Kucera),ted.zobeck@ars.usda.gov (T.M. Zobeck), veronica.acosta-martinez@ars.usda.gov (V. Acosta-Martínez), david.wester@tamuk.edu (D.B. Wester), vivien.allen@ttu.edu (V.G. Allen).
Lal, 2008). Managing agricultural lands for increased soil carbon (C) sequestration not only is important to offset increasing levels of atmospheric $C$ but also enhances agronomic and ecosystem sustainability through associated increases in soil nutrient cycling, aggregate stability, and water holding capacity. In the Texas High Plains, semiarid and extreme weather patterns coupled with dwindling water resources, high erosion potential and inherently low soil organic matter constrains sustainable agricultural production. In this region, numerous studies have highlighted the benefits of integrated crop-livestock agroecosystems (ICL) as an alternative to monoculture cotton, a low-residue returning, high soil disturbance cropping system. Ecological benefits include the reduction of irrigation and energy needs (Allen et al., 2005, 2012; Zilverberg, 2012), increased nutrient supply and C storage (Acosta-Martínez 
et al., 2010; Fultz et al., 2013) and enhanced microbial diversity and functionality (Davinic et al., 2012).

In order to identify agroecosystem management practices that increase $C$ sequestration, it is critical to understand soil organic $C$ (SOC) distribution within soil aggregates (Blanco-Canqui and Lal, 2004). Physical separation of soil into distinct size fractions isolates water stable macroaggregates $(>250 \mu \mathrm{m})$ which helps the soil to resist the erosive forces of water and wind. The stabilization of macroaggregates physically protects soil $\mathrm{C}$ within smaller aggregates pools including intra-aggregate microaggregates (Kong et al., 2005; Six et al., 2000). These physical aggregate fractions have been shown to be sensitive to management practices such as tillage and vegetation type (Grandy and Robertson, 2006; Jagadamma and Lal, 2010; Spohn and Giani, 2011; Yoo et al., 2011) and have been proposed as an indicator of $C$ sequestration (Denef et al., 2007; Kong et al., 2005). The total amount of $C$ sequestered in these protected pools is dependent on the quantity and quality of $\mathrm{C}$ inputs, soil texture, soil moisture and temperature, and management (Denef et al., 2007; Lichter et al., 2008; Simpson et al., 2004). Increased $\mathrm{C}$ in the intra-aggregate fractions, in particular the intraaggregate microaggregates, has been reported under reduced and no-till agroecosystems versus conventional-till (Fultz et al., 2013; Kong et al., 2005; Six et al., 2000).

Common crop and forage management practices include notill production, rotational cropping, and the implementation of perennial forages. Well-managed livestock grazing in ICLs minimally impacted soil physical measurements including bulk density in short-term studies (Franzluebbers and Stuedemann, 2008); however, overgrazing has been shown to increase soils susceptibility to erosion by increasing compaction (Daniel et al., 2002). Shifts in agronomic management practices such as the use of notill have been shown to sequester C, especially in surface soils (Jagadamma and Lal, 2010; Olchin et al., 2008) as disturbances of biomass is reduced. Rotational cropping allows for the diversification of biomass (Moore et al., 2000) which can ultimately result in increased SOC; however, results have varied. In west Texas, no-till continuous cropping resulted in the greatest increase of surface SOC as a result of the increased biomass applied to the surface relative to rotations, which incorporated a fallow period (Potter et al., 1997). Conversion from monoculture cropping to perennial forages is an alternative practice that not only diversifies the cropping agroecosystem but also is a potential sink for atmospheric $\mathrm{C}$ via increased SOC content. Soil organic C increased $22 \%$ over a 13 year period in a Texas High Plains ICL comprised of a perennial forage component and two no-till rotational cropping components (Fultz et al., 2013). Specifically, the perennial forage ICL component had the greatest increase in SOC (31\%) and also greater mean weight diameter over time indicating enhanced aggregate stability and a potential $C$ sink in these semiarid soils (Acosta-Martínez et al., 2004; Fultz et al., 2013).

The numerous combinations of vegetation and livestock choices provide great flexibility for producers to achieve site-specific goals but to identify the drivers of ecological and economic benefits long-term systems-level research is required. The objective of this study was to determine the overall potential for $\mathrm{C}$ sequestration of three contrasting ICLs and two continuous cotton (CTN) agroecosystems by measuring SOC distribution and mean weight diameter in both whole soil and soil aggregates. Two of these long-term ICL agroecosystems were initiated in 2002 to investigate grazing of stocker steers in a variety of crops and forages including a rotation, and both monoculture and mixed perennial grasses under dryland and deficit-irrigation management. The third ICL and one of the continuous cotton agroecosystems were selected from 33 producer-operated farms that are part of the Texas Alliance for Water Conservation program that was initiated in 2005 (TAWC, 2012). Understanding the impacts of these management practices (irrigation type and tillage) and vegetation type on $C$ sequestration will provide detailed information with far-reaching implications (e.g. better C models, C trading, etc.) pertaining to sustainable agriculture in semiarid agroecosystems.

\section{Materials and methods}

\subsection{Study site and management details}

Five agroecosystems were selected to represent continuous cotton (CTN), the dominant form of agricultural production and integrated crop-livestock (ICL) agroecosystems, a potential alternative management practice (Table 1 ). All agroecosystems were located in the Texas High Plains region of northwest Texas. The climate is semiarid with an average annual precipitation of $466 \mathrm{~mm}$ occurring primarily in May through October (NOAA, 2012) and average evapotranspiration of $1500 \mathrm{~mm}$ (Texas ET Network, 2013). All agroecosystems were selected to meet the following criteria: Pullman clay loam soil series (Fine, mixed, superactive, thermic Torrertic Paleustolls), soil with $<1 \%$ slope, same soil moisture and temperature regimes (ustic and thermic, respectively), located within $50 \mathrm{~km}$ of each other and on the same geomorphic landscape position (i.e., uplands on the Llano Estacado) and elevation (994-1005 m), and all vegetation components were fully established within three years of each other (Table 1).

The five agroecosystems included two continuous cotton (CTN) and three ICL agroecosystems. Three agroecosystems (two ICLs and one CTN) were located on the Texas Tech Experimental Farm, six miles east of New Deal, Texas (N33.734040 W101.738706 ${ }^{\circ}$ ). The other two agroecosystems (an ICL and a CTN) were producer-operated and participants in the Texas Alliance for Water Conservation (TAWC) program (TAWC, 2011) and were located near the town of Lockney, TX $\left(34.124518^{\circ} \mathrm{N}, 101.441552^{\circ}\right.$ W) $50 \mathrm{~km}$ northeast of the Texas Tech Experimental Farm. The CTN at the Texas Tech Experimental Farm (CTN_1; 0.25 ha) had been conventionally tilled monoculture cotton since 2006 and was irrigated through subsurface drip-irrigation(SDI) at $1 \mathrm{~m}$ spacing buried to a depth of $30 \mathrm{~cm}$. Fertilizer and irrigation (105 mm in 2010) applications were done through the SDI system. The producer-operated CTN (CTN_2; $41.6 \mathrm{ha}$ ) located $1 \mathrm{~km}$ south of Lockney, TX used a reduced tillage practice with maximum tillage depth of $10 \mathrm{~cm}$. Irrigation and fertilization were applied through SDI ( $1.5 \mathrm{~m}$ spacing buried to a depth of $25 \mathrm{~cm}$ ) with more irrigation in 2009 (305 mm) compared to 2010 (127 mm).

Details for the two Texas Tech Experimental Farm ICL agroecosystems can be found in Zilverberg (2012). In brief, the first ICL was a forage-cotton agroecosystem (FRG_CTN; 10 ha) initiated in 2004 and consisted of two perennial grassland and two annual crop components. Of the two, perennial grasslands, one was a perennial native grassland ( $4.5 \mathrm{ha}$ ) dominated by blue grama [Bouteloua gracilis (Willd. ex Kunth) Lag. ex Griffiths], sideoats grama [Bouteloua curtipendula (Michx.) Torr.], buffalograss [Buchloe dactyloides (Nutt.) J.T. Columbus], and green sprangletop [Leptochloa dubia (Kunth) Nees]. The second grassland was deficit irrigated WW B-Dahl - Old World Bluestem [bluestem1; Bothriochloa bladhii (Retz) S.T. Blake; 2.1 ha], which was incorporated into the FRG_CTN agroecosystem as an additional source of forage in 2009. The annual crop components consisted of one paddock of foxtail millet (Setaria italica [L.] P. Beauv.; 1.7 ha) and one paddock of cotton (FiberMax 9058F; $1.7 \mathrm{ha}$ ) both under conventional tillage and planted in rotation such that both crops were present each year. The perennial native grasslands and the cotton-millet rotation were not irrigated (dryland production) and fertilized through surface applications, typically occurring in April. The cotton and 


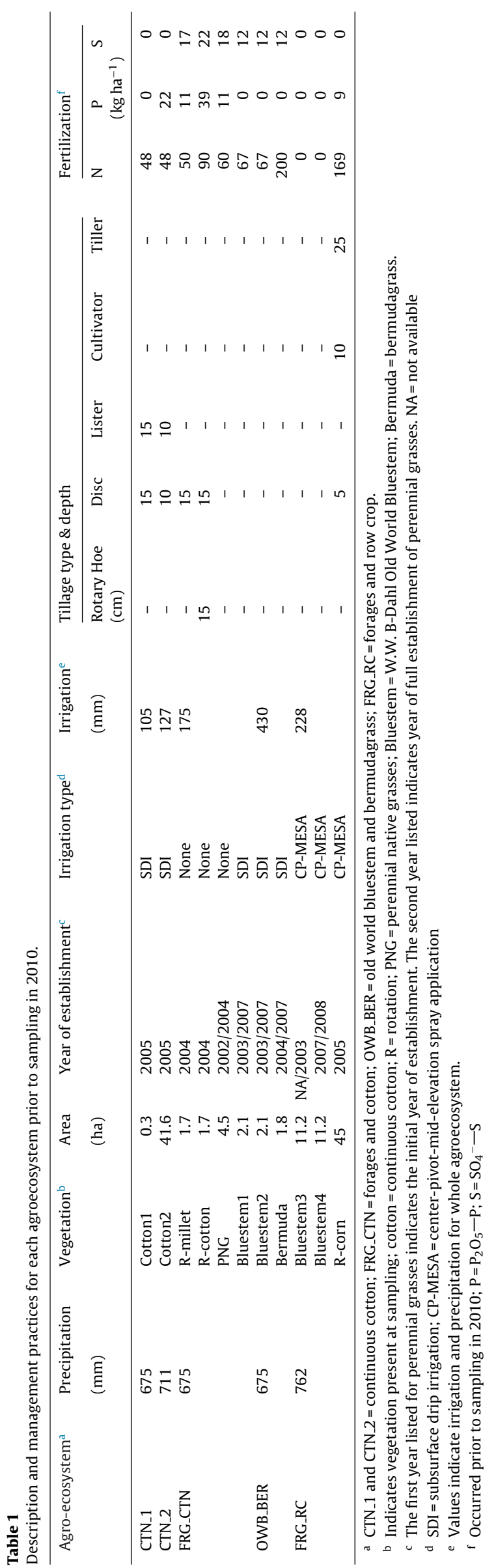

foxtail millet rotation will be referred to as R-cotton and R-millet indicating the vegetation present at time of sampling. Irrigation rates of bluestem 1 in 2009 and 2010 were $241 \mathrm{~mm}$ and $175 \mathrm{~mm}$, respectively.

The second ICL agroecosystem (OWB_BER; 3.9 ha), established by 2007 , consisted of one paddock of bluestem (bluestem $2 ; 2.1$ ha) and two paddocks of bermudagrass [bermuda; Cynodon dactylon (L.) Pers.; 0.9 ha each], which were irrigated and fertilized through SDI ( $1 \mathrm{~m}$ spacing to a depth of $0.4 \mathrm{~m}$ ). To reduce the cost of subsequent analyses, only one bermuda component was sampled and analyzed. Bermuda was irrigated with $305 \mathrm{~mm}$ and $255 \mathrm{~mm}$ in 2009 and 2010, respectively. Bluestem 2 received $269 \mathrm{~mm}$ and $175 \mathrm{~mm}$ in 2009 and 2010, respectively.

Grazing by stocker steers occurred in May through September beginning in 2005. Cattle rotated among the vegetation types depending on growth and maturity. The FRG_CTN agroecosystem (excluding cotton) was grazed by 8 and 10 head in 2009 and 2010, respectively; while the OWB_BER agroecosystem was grazed by 15 head of cattle in both 2009 and 2010. An additional two head of cattle were added in 2009 due to excess forage growth.

The third ICL agroecosystem (FRG_RC; $67.4 \mathrm{ha}$ ), $2.5 \mathrm{~km}$ northwest of Lockney, TX, consisted of rotationally grazed (cow-calf) paddocks of bluestem (bluestem3 and bluestem4; 11.2 ha each) and 45 ha of annual crop production, which was corn (Zea mays; R-corn) in 2010 under conventional tillage to an average depth of $25 \mathrm{~cm}$ and fertilizer applied through surface applications. Previous annual crops produced included cotton (2005 and 2007) and sunflower (2006 and 2009). The bluestem 3 field had been managed for grass forage since 2003, while bluestem 4 was under annual crop production (cotton and corn followed by wheat planted for cover and grazing) until 2007 when bluestem was established for seed harvest and additional grazing. Total irrigation applied via center pivot (MESA) for the total agroecosystem was 178 and $228 \mathrm{~mm}$ in 2009 and 2010, respectively with the majority of the water applied to the cropped area (TAWC, 2012)

\subsection{Soil sample collection}

Soil samples were collected from depths of 0 to 5 (surface) and 5 to $20 \mathrm{~cm}$ (subsurface) in July and August 2010. Within FRG_CTN and OWB_BER five samples, from each of the 3 true blocks, were collected using a zig-zag pattern within each vegetation component, gently mixed by hand to avoid breaking aggregates and composited to provide a representative sample at the vegetation level. The CTN_1, CTN_2, and FRG_RC agroecosystems were not replicated; three areas of equal size for each agroecosystem (i.e. three pseudoreplicates) were identified using satellite images and five random samples were collected using a zig-zag pattern within each pseudo-replicate and composited as described above. Soil was collected with a shovel from a shallow $(22 \mathrm{~cm})$ hole by removing a $5 \mathrm{~cm}$ thick by $13 \mathrm{~cm}$ wide (approximately $1300 \mathrm{~cm}^{3}$ across both depths) slice of soil trimming the edges to obtain a uniform amount of soil at each depth. This method is less disruptive than coring or auguring to better preserve soil aggregates (Lorenz and Dick, 2011). Soil was stored at $4^{\circ} \mathrm{C}$ and within $48 \mathrm{~h}$ of collection, the field-moist soil was gently broken by hand to pass through an 8$\mathrm{mm}$ sieve. Visible plant material was removed and sieved soils were air-dried for three days for subsequent soil aggregate fractionation and chemical analyses. Bulk density was measured using an InstroTek 3500 Xplorer Nuclear Moisture Density Gauge (Las Vegas, NV) at 0-5 and 5-20 cm depths. Particle size analysis was conducted by a combination of sieving and sedimentation techniques as described by Kettler et al. (2001). Based on this method, soils consisted of $42 \%$ sand, $30 \%$ silt, and $28 \%$ clay in $0-5 \mathrm{~cm}$ samples and $42 \%$ sand, $29 \%$ silt, and $29 \%$ clay in $5-20 \mathrm{~cm}$ samples averaged across all sites. 
Table 2

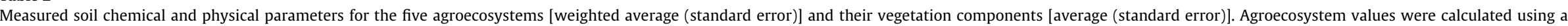
weighted average based on proportional area from each of the components of the system.

\begin{tabular}{|c|c|c|c|c|c|c|c|c|c|}
\hline Depth & Agro-ecosystem $^{a}$ & Vegetation $^{\mathrm{b}}$ & $\begin{array}{l}\text { Vegetation proportion } \\
\text { (\%) }\end{array}$ & $\begin{array}{l}\text { Bulk density } \\
\left(\mathrm{g} \mathrm{cm}^{-1}\right)\end{array}$ & $\begin{array}{l}\text { Mean weight diameter } \\
(\mathrm{mm})\end{array}$ & $\mathrm{pH}$ & $\begin{array}{l}\text { Soil organic matter } \\
\left(\mathrm{Mg} \mathrm{ha}^{-1}\right)\end{array}$ & $\begin{array}{l}\text { Total soil nitrogen } \\
\left(\mathrm{Mg} \mathrm{ha}^{-1}\right)\end{array}$ & $\begin{array}{l}\text { Soil organic carbon } \\
\left(\mathrm{Mg} \mathrm{ha}^{-1}\right)\end{array}$ \\
\hline \multirow{14}{*}{$0-5 \mathrm{~cm}$} & CTN_1 & Cotton $1^{\mathrm{c}}$ & 100.0 & $1.05(0.05) A^{\mathrm{d}} \mathrm{b}^{\mathrm{e}}$ & $0.15(0.01) B d$ & $8.0(0.15) \mathrm{Aa}$ & 9.9 (0.9) BCdef & $0.3(0.02) B C c d$ & $5.2(0.67) A B c d e$ \\
\hline & CTN_2 & Cotton $2^{c}$ & 100.0 & $0.85(0.02) B C$ & $0.20(0.01) B d$ & $7.5(0.09) \mathrm{Bbcd}$ & $6.4(0.6) \mathrm{Cf}$ & $0.2(0.01) C d$ & $3.0(0.02) B e$ \\
\hline & FRG_CTN & R-Millet & 16.6 & $1.09(0.01) \mathrm{ab}$ & $0.20(0.01) \mathrm{d}$ & $7.0(0.09) \mathrm{e}$ & $9.3(0.2)$ ef & $0.3(0.01) \mathrm{cd}$ & $4.0(0.25) \mathrm{de}$ \\
\hline & & R-Cotton & 16.6 & $1.03(0.02) \mathrm{b}$ & $0.21(0.01) \mathrm{d}$ & $7.3(0.09)$ cde & $8.4(0.3)$ ef & $0.3(0.03) \mathrm{cd}$ & $4.1(0.12)$ cde \\
\hline & & PNG & 47.1 & $1.08(0.02) a b$ & $0.43(0.04) \mathrm{bcd}$ & $7.2(0.12) \mathrm{de}$ & $13.1(2.9) \mathrm{bcd}$ & $0.4(0.10) \mathrm{cd}$ & $6.3(1.45) \mathrm{bcd}$ \\
\hline & & Bluestem1 & 19.7 & $1.08(0.01) \mathrm{ab}$ & $0.31(0.01) \mathrm{cd}$ & $7.8(0.06) \mathrm{ab}$ & $10.8(0.9)$ cdef & $0.5(0.04) b c$ & $5.0(0.13)$ cde \\
\hline & \multicolumn{2}{|c|}{ FRG_CTN mean } & & $1.07(0.01) \mathrm{A}$ & $0.28(0.01) B$ & $7.3(0.04) B$ & $11.2(2.6) A B C$ & $0.4(0.05) A B$ & $5.3(0.72) A$ \\
\hline & OWB_BER & Bluestem2 & 53.6 & $1.09(0.02) a b$ & $0.31(0.01) \mathrm{cd}$ & $7.6(0.10) b c$ & $12.2(0.6)$ cde & $0.4(0.03) \mathrm{cd}$ & $5.9(0.50)$ cde \\
\hline & & Bermuda & 46.4 & $1.09(0.01) \mathrm{ab}$ & $0.60(0.08) b c$ & $7.6(0.20) b c$ & $14.5(1.0) \mathrm{abc}$ & $0.5(0.08) b c$ & $7.1(0.90) b c$ \\
\hline & \multicolumn{2}{|c|}{ OWB_BER mean } & & $1.09(0.00) \mathrm{A}$ & $0.75(0.08) A$ & $7.6(0.07) A B$ & $13.3(1.4) \mathrm{A}$ & $0.5(0.05) A$ & $6.4(0.68) A$ \\
\hline & FRG_RC & Bluestem3 & 16.3 & $1.19(0.05) \mathrm{a}$ & $1.59(0.22) \mathrm{a}$ & $7.7(0.12) a b$ & $18.7(1.4) \mathrm{a}$ & $0.8(0.08) \mathrm{a}$ & $10.2(1.37) \mathrm{a}$ \\
\hline & & Bluestem4 & 17.7 & $1.15(0.05) \mathrm{ab}$ & $0.73(0.11) \mathrm{b}$ & $7.6(0.07) a b c$ & $18.4(2.2) \mathrm{ab}$ & $0.7(0.09) \mathrm{ab}$ & $9.1(0.73) a b$ \\
\hline & & R-corn & 66.0 & $0.89(0.02) \mathrm{c}$ & $0.31(0.06) \mathrm{cd}$ & $7.7(0.03) a b$ & $10.3(0.4) \mathrm{cde}$ & $0.4(0.03) \mathrm{cd}$ & $4.9(0.36)$ cde \\
\hline & \multicolumn{2}{|c|}{ FRG $R C$ mean } & & $1.08(0.09) \mathrm{A}$ & $0.91(0.05) A$ & $7.7(0.07) A B$ & $13.1(1.0) A B$ & $0.5(0.03) A$ & $6.5(0.50) A$ \\
\hline \multirow[t]{14}{*}{$5-20 \mathrm{~cm}$} & CTN_1 & Cotton $1^{c}$ & 100.0 & $1.41(0.02)$ Aabc & $0.16(0.01) D d$ & $8.3(0.03) \mathrm{Aa}$ & $42.2(0.5) A B a b$ & $1.1(0.09) A B c d$ & 14.9 (1.25) Aabc \\
\hline & CTN_2 & Cotton $2^{c}$ & 100.0 & $1.22(0.03) C d$ & $0.29(0.02) C \mathrm{~cd}$ & $7.9(0.12) B a b c$ & $23.7(3.5) B C$ & $0.8(0.08) B d$ & $10.4(0.32) B C$ \\
\hline & FRG_CTN & R-Millet & 16.6 & $1.40(0.01) \mathrm{bc}$ & $0.16(0.01) \mathrm{d}$ & $7.9(0.12) a b c$ & $39.1(2.8) a b$ & $1.1(0.07) \mathrm{cd}$ & $13.1(0.57) \mathrm{bc}$ \\
\hline & & R-Cotton & 16.6 & $1.40(0.02) \mathrm{c}$ & $0.15(0.01) \mathrm{d}$ & $7.6(0.12) \mathrm{ac}$ & $34.2(2.1) b c$ & $1.2(0.07) \mathrm{bcd}$ & $12.8(1.36) \mathrm{bc}$ \\
\hline & & PNG & 47.1 & $1.43(0.01) \mathrm{abc}$ & $0.45(0.03) \mathrm{bc}$ & $7.9(0.10) b c$ & $37.3(4.2) \mathrm{bc}$ & $1.2(0.13) \mathrm{bcd}$ & $14.5(2.12) \mathrm{abc}$ \\
\hline & & Bluestem 1 & 19.7 & $1.45(0.01) \mathrm{abc}$ & $0.28(0.03) \mathrm{cd}$ & $8.1(0.06) a b$ & $36.2(0.4) b c$ & $1.1(0.03) \mathrm{cd}$ & $14.5(0.18) a b c$ \\
\hline & \multicolumn{2}{|c|}{ FRG_CTN mean } & & $1.42(0.01) \mathrm{A}$ & $0.26(0.01) C$ & $7.9(0.08) B$ & $36.7(1.1) A B$ & $1.2(0.09) \mathrm{A}$ & $14.1(1.27) A B$ \\
\hline & OWB_BER & Bluestem2 & 53.6 & $1.44(0.01) \mathrm{abc}$ & $0.17(0.01) \mathrm{d}$ & $8.0(0.06) \mathrm{ab}$ & $39.6(1.1) a b$ & $1.2(0.06) \mathrm{bcd}$ & $15.3(0.65) \mathrm{abc}$ \\
\hline & & Bermuda & 46.4 & $1.42(0.01) \mathrm{abc}$ & $0.29(0.01) \mathrm{cd}$ & $7.8(0.13) b c$ & $39.9(2.6) \mathrm{ab}$ & $1.5(0.23) a b c$ & $18.3(3.10) \mathrm{ab}$ \\
\hline & \multicolumn{2}{|c|}{ OWB_BER mean } & & $1.43(0.01) A$ & $0.38(0.00) B$ & $7.9(0.06) B$ & $39.7(0.3) A$ & $1.3(0.14) \mathrm{A}$ & $16.7(1.75) \mathrm{A}$ \\
\hline & FRG_RC & Bluestem3 & 16.3 & $1.48(0.01) \mathrm{a}$ & $1.07(0.17) \mathrm{a}$ & $8.1(0.03) a b$ & $44.4(2.1) \mathrm{ab}$ & $1.8(0.25) \mathrm{a}$ & $20.1(0.93) \mathrm{a}$ \\
\hline & & Bluestem4 & 17.7 & $1.47(0.04) \mathrm{ab}$ & $0.57(0.03) \mathrm{b}$ & $8.1(0.06) a b$ & $50.8(4.3) \mathrm{a}$ & $1.6(0.20) \mathrm{ab}$ & $19.8(1.56) \mathrm{a}$ \\
\hline & & R-corn & 66.0 & $1.09(0.01) \mathrm{e}$ & $0.51(0.10) b c$ & $7.8(0.06) b c$ & $34.8(1.8) a b c$ & $1.1(0.12) \mathrm{cd}$ & $14.0(0.82) \mathrm{bc}$ \\
\hline & \multicolumn{2}{|c|}{ FRG_RC mean } & & $1.35(0.13) B$ & $0.70(0.05) A$ & $8.0(0.01) A B$ & $39.2(1.2) A B$ & $1.3(0.12) A$ & $16.0(0.86) \mathrm{A}$ \\
\hline
\end{tabular}

a ${ }^{2}$ TN_1 and CTN_2 = continuous cotton; FRG_CTN = forage and cotton; OWB_BER = old world bluestem and bermudagrass; FRG_RC= forage and row crop.

${ }^{\mathrm{b}}$ Indicates dominant vegetation at time of sampling.

c CTN1 and CTN2 indicate both agroecosystem mean and vegetation component values.

d Similar upper case letters at same depth indicate no significant difference between agroecosystems at $\alpha=0.01$

e Similar lower case letters at same depth indicate no significant difference between vegetation components at $\alpha=0.01$. 


\subsection{Aggregate fractionation}

Isolation of both water stable aggregates and intra-aggregate fractions were performed according to the methods described by Elliott (1986) and Six et al. (2000). The initial aggregate fractionation was originally described by Elliott (1986) and isolated four water stable aggregate fractions that were the result of slaking the soil sample on a $2000 \mu \mathrm{m}$ sieve. Following slaking for $5 \mathrm{~min}$, size fractions were obtained by collecting material that remained on successively smaller sieves $(2000,250$, and $53 \mu \mathrm{m})$ following physical oscillation $(3 \mathrm{~cm})$ of each sieve 50 times over a 2 min period. Water stable aggregates included macroaggregates $(>250 \mu \mathrm{m})$, microaggregates $(53-250 \mu \mathrm{m})$, and a silt + clay $(<53 \mu \mathrm{m})$ fraction. Macroaggregates were further broken down into three intra-aggregate fractions as described by Six et al. (2000). Briefly, a subsample of macroaggregates was placed in a device containing a $250 \mu \mathrm{m}$ screen with 50 glass beads ( $4 \mathrm{~mm}$ ). A combination of physical disturbance (shaking) and continuous flow of water completely dispersed macroaggregates with the material passing through the $250 \mu \mathrm{m}$ screen collected on a $53 \mu \mathrm{m}$ sieve set above a catchment basin. Intra-aggregate particulate organic matter (POM; $>250 \mu \mathrm{m}$ ) remained on the $250 \mu \mathrm{m}$ screen, while intra-aggregate microaggregates $(53-250 \mu \mathrm{m})$ were those which remained on the $53 \mu \mathrm{m}$ sieve following the wet sieving process described above, and the intra-aggregate silt + clay $(<53 \mu \mathrm{m})$ fraction was material which passed through the $53 \mu \mathrm{m}$ sieve into the catchment basin. To correct for sand content, subsamples of macroaggregate and microaggregate fractions were dispersed in a sodium hexametaphosphate $(0.5 \%)$ solution and shaken for $15 \mathrm{~h}$ on a rotary shaker before being sieved through a $53 \mu \mathrm{m}$ sieve (Elliott et al., 1991).

Mean weight diameter, an indicator of aggregate stability, was calculated based on the proportion of the soils from each of the three sand-free water stable aggregate classes obtained from each sample. Calculations were done using the following equation:

Mean weight diameter $=\sum_{i} P_{i} D_{i}$

where $P_{i}$ is the proportion of the whole soil in the given fraction, and $D_{i}$ is the average diameter $(\mathrm{mm})$ of the particles of the fraction (van Bavel, 1950).

\subsection{Soil chemical analyses}

Chemical analyses on whole soils were done through an independent lab (Ward Lab; Kearney, NE) and included pH (1:1) and soil organic matter (SOM; \% loss-on-ignition; LOI). Subsamples of each fraction and whole soil were hand ground to a fine powder and total nitrogen and total $\mathrm{C}$ content was determined by dry combustion analysis using a LECO TruSpec CN analyzer (St. Joseph, MI). Presence of inorganic $\mathrm{C}$ (i.e., carbonate $\mathrm{C}$ ) was examined through acidification with $1: 1 \mathrm{HCl}: \mathrm{H}_{2} \mathrm{O}$ solution (non-carbonate carbon method; LECO) of a subset of samples that covered the range of soil $\mathrm{pH}(6.9-8.3)$ prior to analysis. Following acidification, samples were re-analyzed using dry combustion and no detectable inorganic $C$ was measured within the soil samples, thus measured total C represents SOC. Bulk density was used to determine total nitrogen, SOC and SOM content on an area basis $\left(\mathrm{kg} \mathrm{ha}^{-1}\right)$.

\subsection{Statistical analyses}

Depths (0-5 and 5-20 cm) were analyzed separately. Data analyses were performed at two separate levels: agroecosystems and individual vegetation components. Agroecosystems values were calculated based on weighted averages using the proportional area of each vegetation component within a specific agroecosystem (OWB_BER - $54 \%$ bluestem and $46 \%$ bermuda). Two systems

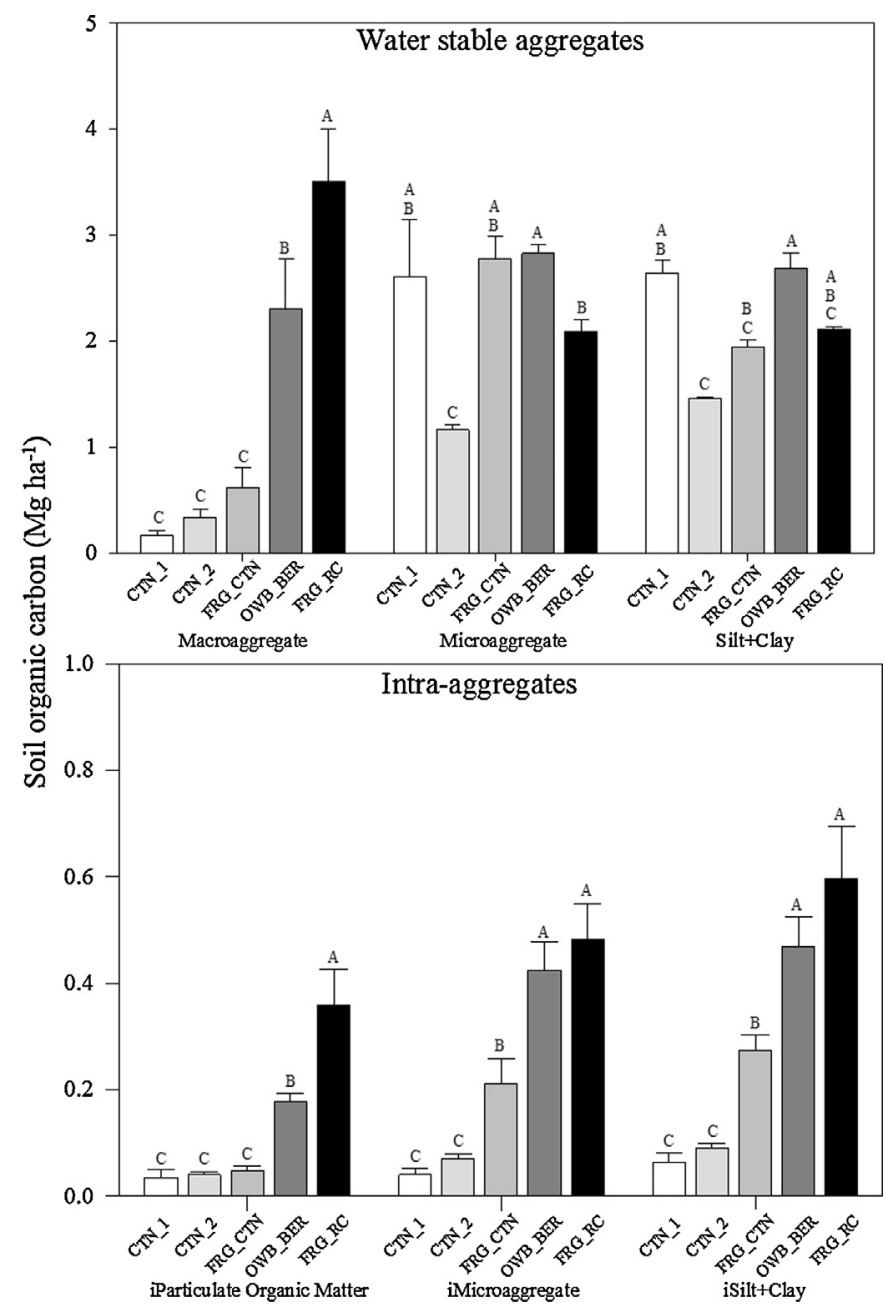

Fig. 1. Soil organic carbon (SOC) content from (a) water stable aggregates and (b) intra-aggregates (i) at the agroecosystem level in surface $(0-5 \mathrm{~cm})$ soils. Values were calculated using a weighted average based on the proportional area for each vegetation component within a system. Error bars indicate standard error. Different letters within an aggregate fraction indicates significant differences at $\alpha=0.01$. CTN_1 and CTN_2 = continuous cotton; FRG_CTN = forage and cotton integrated croplivestock agorecosystem (ICL); OWB_BER = old world bluestem and bermudagrass ICL; FRG_RC = forage and row crop ICL.

(FRG_CTN and OWB_BER) incorporated true replication via establishment of 3 true blocks in a randomized block design. However, 3 systems (CTN_1, CTN_2 and FRG_RC) were not replicated in space; for these systems, we established 3 pseudoreplications. To account for the facts that (i) data from two experimental designs (a true randomized block design and a pseudoreplicated completely randomized design) were to be analyzed together, and (ii) our scope of inference is limited because of pseudoreplication of 3 systems (Wester, 1992), the data for all agroecosystems were analyzed as if they were completely randomized designs with respect to the "system" (or "vegetation") factor under evaluation. Although this approach pools the degrees of freedom associated with blocks (in the true block designs) with the error term, it also pools the corresponding variation with this error term; whereas the former tends to inflate rejection rates, the latter tends to deflate rejection rates. Because data corresponding to the aggregate fractions were collected from each experimental unit, the aggregate fraction factor was analyzed as a subplot factor in a split plot arrangement. Therefore, a linear mixed model was analyzed, with system (or vegetation component), fraction and their interaction included as fixed effects and pseudoreplication nested within system as a random effect to 


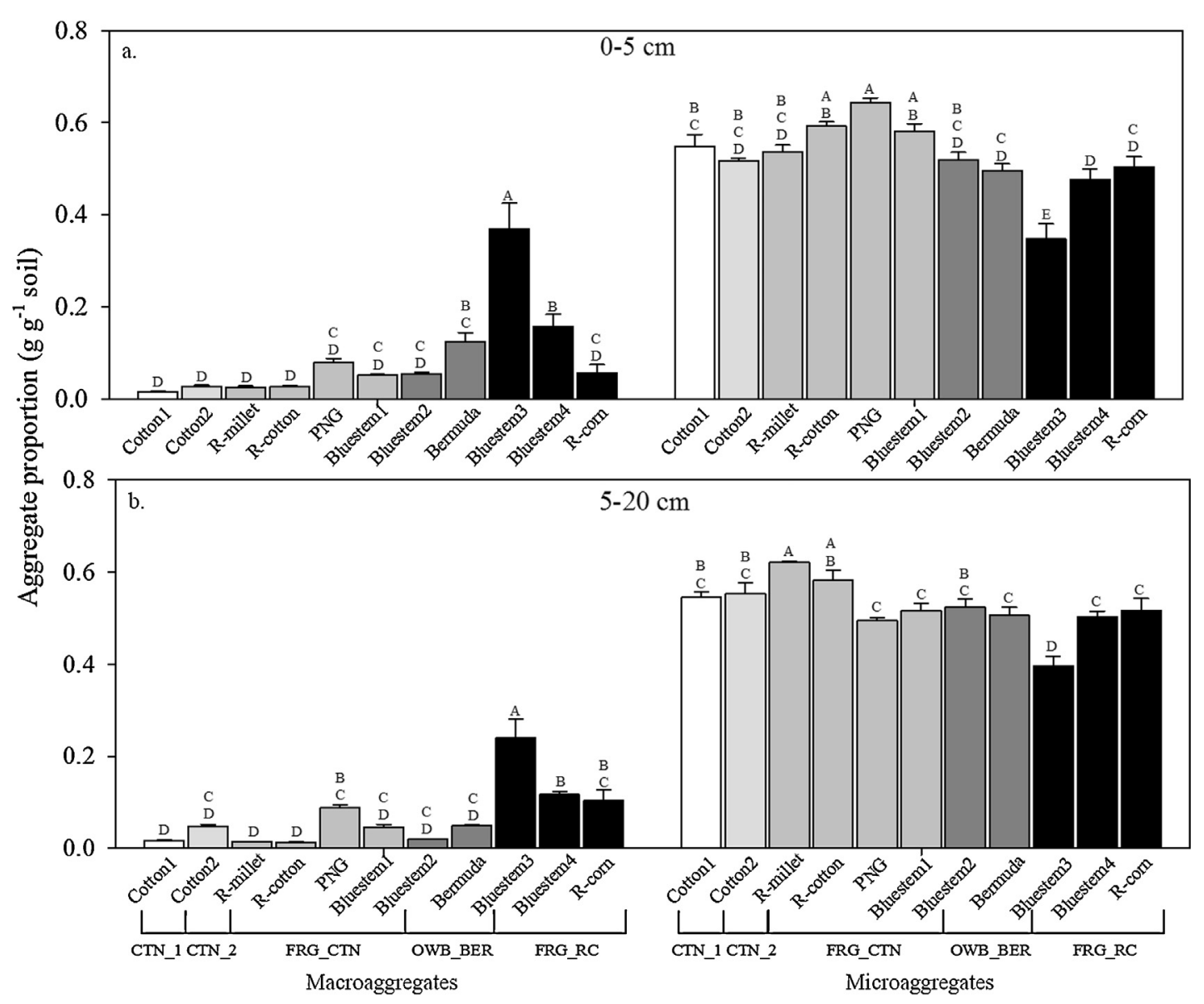

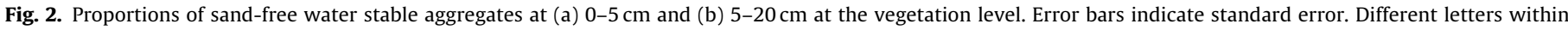

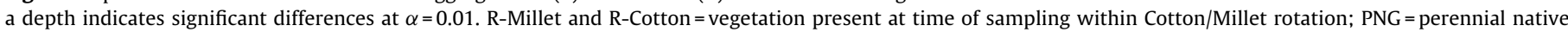
grasses; Bluestem1-4 =W.W. B-Dahl Old World Bluestem.

test the system effect. Data were analyzed with the mixed procedure in SAS (version 9.2). Agroecosystems or vegetation effects were considered significant on aggregate $C$ content with a level of significance of 0.05 for main effects (i.e. agroecosystem, vegetation, or aggregate fraction) and 0.01 for all pair-wise comparisons. This lower $p$-value was used to control for experimental wise error when large numbers of comparisons were done.

\section{Results}

\subsection{Agroecosystems}

At the agroecosystems level, soil $\mathrm{pH}$ ranged from 7.3 to 8.0 in surface samples and 7.9 to 8.3 in subsurface samples with highest $\mathrm{pH}$ in CTN_1 (Table 2). Soil organic matter ranged from 9.78 to $13.27 \mathrm{Mgha}^{-1}$ soil in surface samples with the $48 \%$ more in OWB_BER relative to CTN_1 and CTN_2. Fewer statistical differences were detected in subsurface samples with greater concentrations in CTN_1 and OWB_BER (42.16 and 39.74 $\mathrm{Mg} \mathrm{ha}^{-1}$ soil, respectively). Total nitrogen was greater (44\%) in surface samples from FRG_RC compared to CTN_1 and CTN_2. However, in subsurface soils total nitrogen was greater (48\%) in FRC_RC than CTN_2. Soil organic carbon content was greater in FRG_RC and OWB_BER in the surface samples (avg.: $6.5 \mathrm{Mg} \mathrm{ha}^{-1}$ ), however differences were not found in subsurface samples (Table 2). The surface mean weight diameter in FRG_RC and OWB_BER was $119 \%$ greater than FRG_CTN, CTN_1, and CTN_2 (Table 2). Within subsurface samples agroecosystems ranked as follows: FRG_RC $>$ OWB_BER $>$ CTN_2 $=$ FRG_CTN $>$ CTN_1.
Within water stable aggregates (large and small), SOC content in surface macroaggregates was greatest in FRG_RC $\left(3.5 \mathrm{Mg} \mathrm{ha}^{-1}\right)$, followed by OWB_BER (2.3 Mgha-1) and by FRG_CTN, CTN_2, and CTN_1 (avg.: $0.4 \mathrm{Mg} \mathrm{ha}^{-1}$ ) (Fig. 1a). Microaggregate SOC was significantly lower in CTN_2 (1.2 $\left.\mathrm{Mgha}^{-1}\right)$ when compared to the other four agroecosystems $\left(2.6 \mathrm{Mg} \mathrm{ha}^{-1}\right)$. Within the silt+clay fraction, SOC content in CTN_2 was significantly lower than in CTN_1. Subsurface SOC content in the macroaggregate fraction was greatest in FRG_RC compared to the other four agroecosystems. No significant differences were measured between agroecosystems within microaggregates and silt+clay fractions (avg.: 7.5 and $7.5 \mathrm{Mgha}^{-1}$, respectively).

Soil organic $\mathrm{C}$ content in the intra-aggregate POM was $163 \%$ greater in FRG_RC $\left(0.4 \mathrm{Mg} \mathrm{ha}^{-1}\right)$ compared to FRG_CTN, CTN_2, and CTN_1 (avg.: $0.04 \mathrm{Mg} \mathrm{ha}^{-1}$ ) (Fig. 1b). In the intraaggregate microaggregate fraction, significantly greater (157\%) SOC was measured in FRG_RC and OWB_BER compared to CTN_1 and CTN_2. A similar trend was measured in the intra-aggregate silt + clay fraction with greater SOC content in FRG_RC and OWB_BER (0.5 $\left.\mathrm{Mgha}^{-1}\right)$ than CTN_2 and CTN_1 (0.08 $\mathrm{Mg} \mathrm{ha}^{-1}$, respectively). No significant differences in SOC content were measured between agroecosystems in the subsurface intra-aggregate POM fraction (data not shown). Intraaggregate microaggregate SOC content was significantly greater in FRG_RC (1.6 Mg ha $\left.{ }^{-1}\right)$ compared to CTN_1 (0.02 $\left.\mathrm{Mg} \mathrm{ha}^{-1}\right)$. Intra-aggregate silt+clay SOC content was greatest in FRG_RC $\left(1.7 \mathrm{Mg} \mathrm{ha}^{-1}\right)$, followed by FRG_CTN $\left(0.9 \mathrm{Mgha}^{-1}\right)$ and lowest in CTN_1 (0.3 $\left.\mathrm{Mg} \mathrm{ha}^{-1}\right)$. 


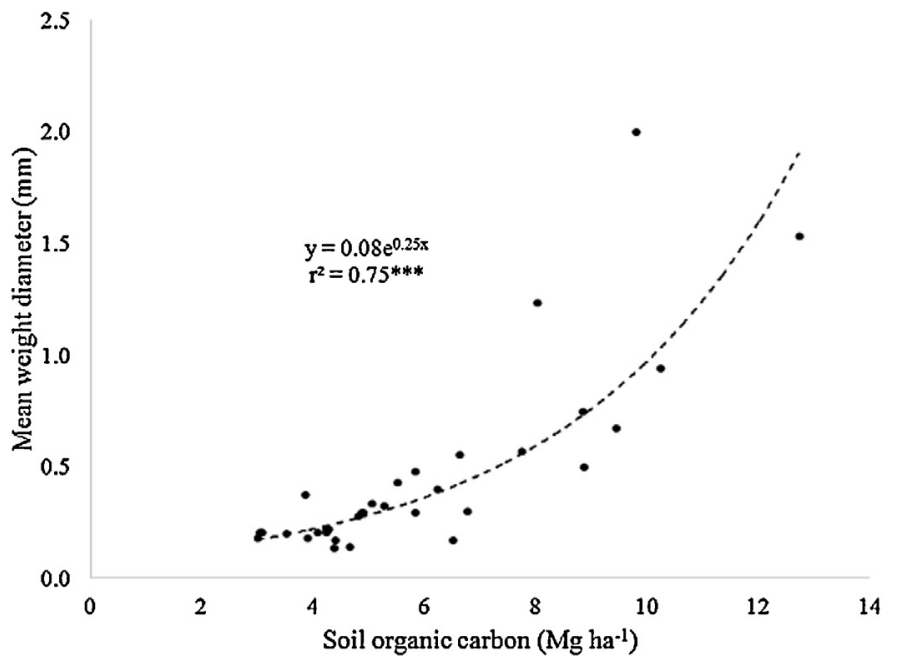

Fig. 3. Mean weight diameter as a function of soil organic carbon content $\left(\mathrm{Mg} \mathrm{ha}^{-1}\right)$ for surface soil $(0-5 \mathrm{~cm})$ from all vegetation components. $\left({ }^{* * *} \alpha=0.001\right)$.

\subsection{Vegetation components of the ICLs}

Quantities of macroaggregates (large and small) were greatest in bluestem $3\left(0.37 \mathrm{gg}^{-1}\right.$ soil) followed by bluestem 4 and bermuda (avg.: $0.14 \mathrm{gg}^{-1}$ soil) (Fig. $2 \mathrm{a}$ ). As a group, cotton1, cotton2, R-millet, R-cotton, bluestem 1 and bluestem 2 had the lowest proportion of macroaggregates $\left(0.04 \mathrm{~g} \mathrm{~g}^{-1}\right.$ soil). In contrast, proportions of microaggregates in surface samples were greater in $\mathrm{R}$-cotton, perennial native grasses, and bluestem 1 (avg.: $0.61 \mathrm{~g} \mathrm{~g}^{-1}$ soil) and lowest in bluestem $3\left(0.34 \mathrm{~g} \mathrm{~g}^{-1}\right.$ soil). Macroaggregate proportions in subsurface samples were greatest in bluestem 3 $\left(0.24 \mathrm{~g} \mathrm{~g}^{-1}\right.$ soil), intermediate in bluestem 2 , R-corn, and perennial native grasses $\left(0.1 \mathrm{~g} \mathrm{~g}^{-1}\right.$ soil), and statistically lowest in cotton 1 , R-millet, and R-cotton ( $0.02 \mathrm{gg}^{-1}$ soil) (Fig. 2b). Overall, microaggregates in both surface and subsurface samples dominated the distribution of aggregates in all agroecosystems (Fig. 2); however, within bluestem 3 surface samples, macroaggregate and microaggregate proportions were equally distributed. The proportion of silt + clay was not significantly different between vegetation components at both depths.

The largest mean weight diameter in surface samples was in bluestem $3(1.59 \mathrm{~mm})$ followed by bluestem 4 and bermuda (avg.: $0.66 \mathrm{~mm}$ ) compared to cotton1, cotton2, R-millet, and R-cotton

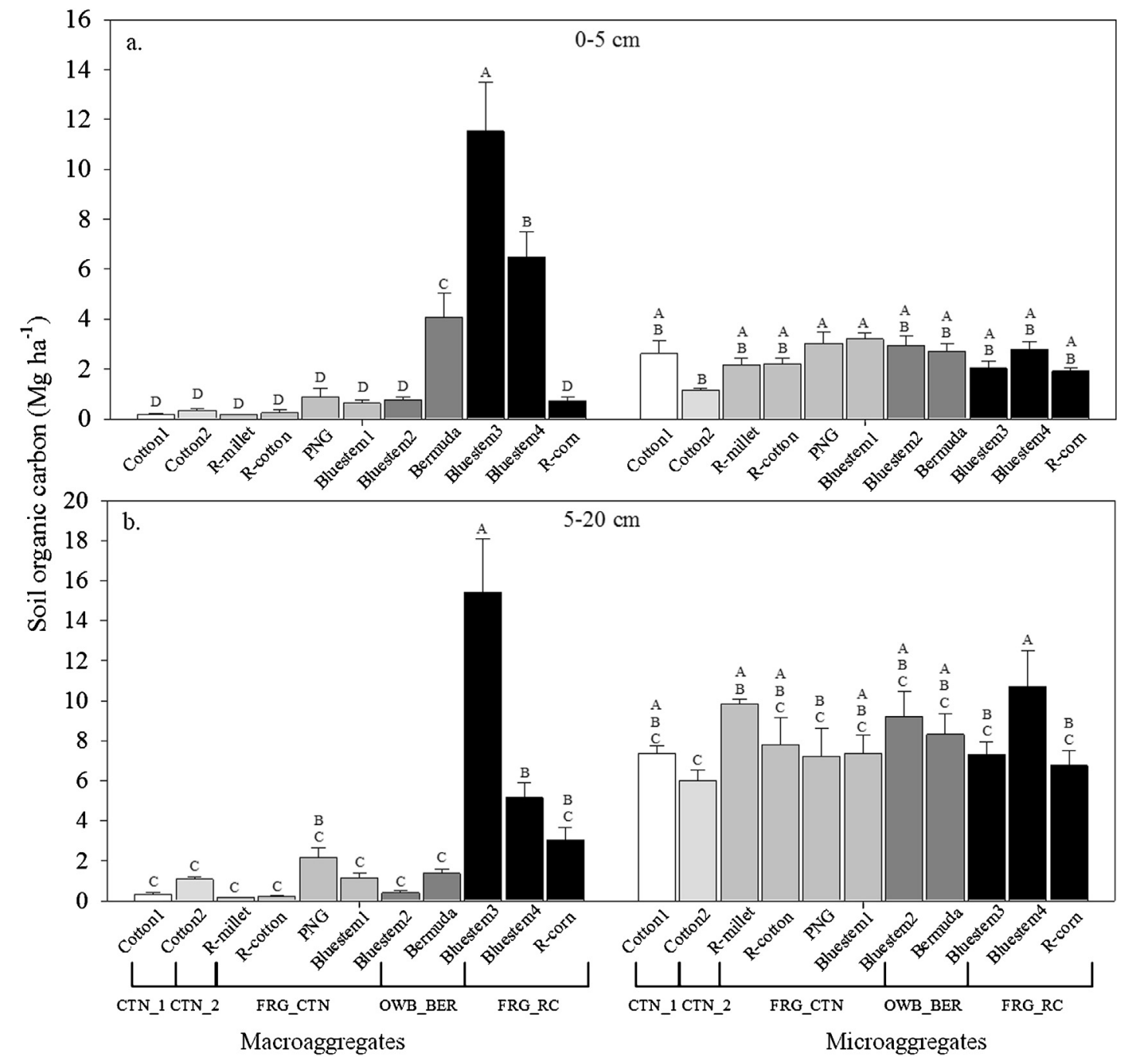

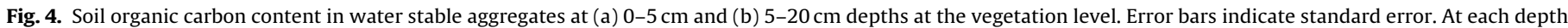

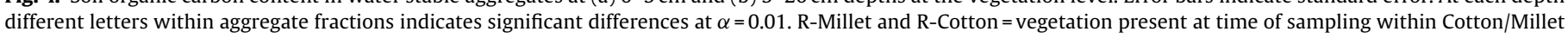
rotation; PNG = perennial native grasses; Bluestem1-4 =W.W. B-Dahl Old World Bluestem. 
(avg.: $0.19 \mathrm{~mm}$ ) (Table 2). In subsurface samples, mean weight diameter was also largest in bluestem $3(1.07 \mathrm{~mm})$, followed by bluestem4, R-corn, and perennial native grasses (avg.: $0.51 \mathrm{~mm}$ ), which were larger than cotton1, R-millet, R-cotton, and bluestem2 (avg.: $0.16 \mathrm{~mm}$ ). In both surface and subsurface samples, bluestem 3 and bluestem 4 had a larger mean weight diameter compared to bluestem 1 and bluestem 2 . In subsurface samples only, R-corn had a larger mean weight diameter than in R-cotton and R-millet. A significant exponential relationship was measured between mean weight diameter and SOC content in all surface samples $\left(r^{2}=0.75\right.$, $p=0.001$ ) (Fig. 3). The point where there was a significant increase in slope was calculated as $5.5 \mathrm{Mg} \mathrm{ha}^{-1}$ soil indicating that mean weight diameter increased more when SOC content exceeded this value. As SOM and SOC were correlated $\left(r^{2}=0.89 ; p=0.001\right)$, the corresponding SOM level was calculated as $11.4 \mathrm{Mg} \mathrm{ha}^{-1}$.

Soil organic matter in surface samples was greater in bluestem3, bluestem4, and bermuda (avg.: $17.23 \mathrm{Mg} \mathrm{ha}^{-1}$ soil) compared to cotton1, cotton2, R-millet, and R-cotton (avg.: $8.49 \mathrm{Mg} \mathrm{ha}^{-1}$ soil) (Table 2). Differences in SOM were measured among the bluestems with $48 \%$ more SOM in bluestem 3 and bluestem 4 compared to bluestem 1 and bluestem2. Greater subsurface SOM was measured in bluestem 3 compared to bluestem1, perennial native grasses R-cotton, and cotton2. Additionally, greater total carbon content in surface samples was measured in bluestem 3 and 4 (avg.: 9.7 $\left.\mathrm{Mg} \mathrm{ha}^{-1}\right)$ than all other vegetation components, except for bermuda ( $\left.7.09 \mathrm{Mg} \mathrm{ha}^{-1}\right)$. Greater SOC content was measured in bluestem3, bluestem4, and bermuda followed by perennial native grasses with lower SOC in R-millet, R-cotton, and cotton2 (Table 2). In the subsurface samples, significantly lower SOC content was measured in R-millet, R-cotton and cotton 2 when compared to bluestem3, bluestem 4 , and bermuda. The SOC content in macroaggregates was greater in bluestem $3\left(11.5 \mathrm{Mg} \mathrm{ha}^{-1}\right)$, followed by bluestem4 (6.5 $\left.\mathrm{Mg} \mathrm{ha}^{-1}\right)$, and bermuda (4.1 $\mathrm{Mg} \mathrm{ha}^{-1}$ ) while lower in the remaining vegetation components (avg.: $0.4 \mathrm{Mg} \mathrm{ha}^{-1}$ ) (Fig. 4a). Soil organic carbon in the surface microaggregate fraction was only significantly different ( $86 \%$ greater) for bluestem 1 and 2 and perennial native grass (avg.: $3.0 \mathrm{Mg} \mathrm{ha}^{-1}$ ) compared to cotton2 $\left(1.2 \mathrm{Mg} \mathrm{ha}^{-1}\right)$. Similar to surface samples, SOC was higher in macroaggregates under bluestem $3\left(15.4 \mathrm{Mgha}^{-1}\right)$ with the lowest content in the $\mathrm{D}$ - and B- bluestem, bermuda, R-millet, Rcotton, cotton 1 and cotton2 (avg.: $0.7 \mathrm{Mg} \mathrm{ha}^{-1}$ ) (Fig. 4b). Within subsurface microaggregates, SOC was significantly greater under bluestem2 and R-millet (avg.: $10.3 \mathrm{Mg} \mathrm{ha}^{-1}$ ) compared to cotton2 (6.0 $\mathrm{Mg} \mathrm{ha}^{-1}$ ).

Soil organic $\mathrm{C}$ content in the intra-aggregate POM was significantly greater under bluestem 3 and bluestem 4 (avg.: $0.9 \mathrm{Mg} \mathrm{ha}^{-1}$ ) compared to all other vegetation components (avg.: $0.07 \mathrm{Mgha}^{-1}$ ) (Fig. 5a). Within the intra-aggregate microaggregates, SOC content was greater under bluestem3 (1.4 $\left.\mathrm{Mg} \mathrm{ha}^{-1}\right)$ and bluestem $2\left(0.9 \mathrm{Mg} \mathrm{ha}^{-1}\right)$ compared to all other vegetation components with the exception of bermuda. Although not significant, greater SOC tended to be measured in the intra-aggregate

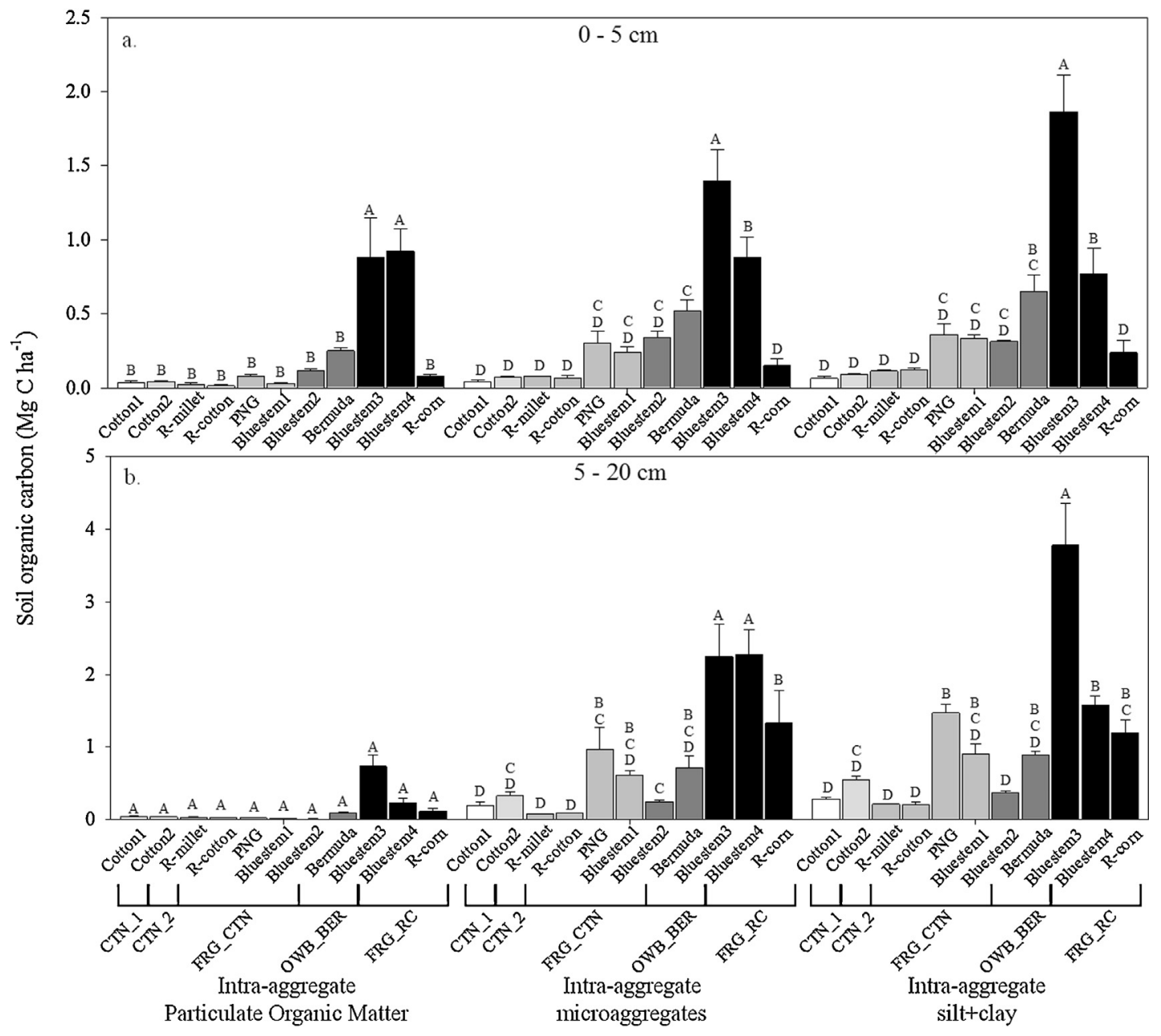

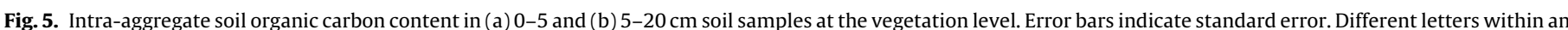

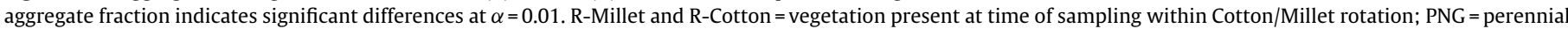
native grasses; Bluestem1-4 =W.W. B-Dahl Old World Bluestem. 
microaggregate fraction under perennial vegetation relative to annual crop soils. Intra-aggregate silt + clay SOC was greatest in bluestem3, followed by bluestem 4 and bermuda and all other components had significantly lower SOC. Although not statistically significant, bluestem 3 resulted in the greatest content of subsurface POM-SOC $\left(0.7 \mathrm{Mgha}^{-1}\right)$ relative to all the other vegetation components (Fig. 5b). Bluestem 3 and bluestem 4 intraaggregate microaggregates contained greater quantities of SOC (avg.: 2.3 $\mathrm{Mg} \mathrm{ha}^{-1}$ ), followed by R-corn and perennial native grasses (avg.: $1.1 \mathrm{Mgha}^{-1}$ ) with lowest intra-aggregate microaggregate SOC content in cotton1, cotton2, R-millet, R-cotton, and bluestem2 (avg.: $0.2 \mathrm{Mg} \mathrm{ha}^{-1}$ ). Significantly greater intra-aggregate silt + clay SOC was measured in bluestem3 (3.8 $\mathrm{Mg} \mathrm{ha}^{-1}$ ), followed by perennial native grass, bluestem4, and R-corn (avg.: $1.4 \mathrm{Mg} \mathrm{ha}^{-1}$ ), with lower SOC in bluestem2, R-cotton, R-millet, and cotton1 (avg.: $0.3 \mathrm{Mg} \mathrm{ha}^{-1}$ ).

\section{Discussion}

In a region prone to soil erosion as a result of previous agricultural practices and frequent drought, management practices which increase aggregate stability and $C$ sequestration potential are particularly important. Of the five agroecosystems studied, FRG_RC and OWB_BER had the overall greatest positive impact on SOM, SOC, aggregate stability, and intra-aggregate microaggregate SOC content followed by the FRG_CTN, CTN_2, and CTN_1. The ability of the ICL agroecosystems to retain SOC was influenced by management and vegetation components. Compared to CTN systems, ICL management was characterized by the inclusion of reduced soil disturbance (no-till) components and increased above- and below-ground vegetative residues associated with perennial grasses ranging from $2100 \mathrm{~kg}$ forage mass ha ${ }^{-1}$ from perennial native grasses to $3300 \mathrm{~kg}$ forage mass ha ${ }^{-1}$ from bluestem components (Zilverberg, 2012). Although there were common management practices across the three ICLs (i.e. perennial grasses and rotational cropping), the site-specific nature of these systems highlights the importance of evaluating individual vegetation components within each agroecosystem.

Greater residues from the perennial grasses (bluestem, bermuda, and native grasses) provided the biomass needed to increase SOM content (Conant et al., 2001; Gale and Cambardella, 2000) via the processing of a larger and more diverse microbial community (Acosta-Martínez et al., 2004; Davinic et al., 2012). These conditions provided the stable soil environment needed for formation of water stable macroaggregates, which increase water storage, resist erosion, and increase $\mathrm{C}$ sequestration by physically protecting $C$ within the intra-aggregate fractions (Fultz et al., 2013; Grandy and Robertson, 2006; Jagadamma and Lal, 2010). This was further demonstrated by the relationship between mean weight diameter and SOC which identified a critical level (5.5 Mg ha-1) of SOC, only found under the perennial grasses. Within the cotton 1 and cotton 2 components, SOC was below this critical level and thus greater SOC content was not sufficient to significantly influence mean weight diameter.

The vegetation components with the greatest $C$ sequestration potential and soil stability included perennial grasses, irrigated diverse crop rotations ( $\mathrm{R}$-corn), and reduced tillage practices (cotton 1 ). This is especially important in the Texas High Plains regions because it implies that as water resources decline, producers have options to assist during the transition from $100 \%$ conventional, fully irrigated monoculture cotton to dryland or deficit-irrigated crops or ICLs. The producer-operated FRG_RC had the greatest soil $C$ sequestration potential, as indicated by greater intra-aggregate microaggregate SOC, where half of the land was fully irrigated annual crops with two grazed bluestem fields (bluestem 3 and bluestem4) on the other half. Within this productive system, the greatest proportion of water stable macroaggregates in bluestem 3 reflected the longer time this field had been under perennial vegetation ( 7 yrs) compared to bluestem 4 (3 yrs). The system that relied entirely on perennial grasses, OWB_BER followed the FRG$\mathrm{RC}$ system in $C$ sequestration potential and mean weight diameter, which may be related to the level of irrigation (deficit irrigated) and the fewer years under perennial grasses (grasses were not fully established until 2007). The FRG_CTN system, ranked the lowest among ICLs, which was likely attributed to the majority of the land being under dryland production (80\% of total area) and $43 \%$ of this area was a tilled annual rotation with less residues added compared to bluestem or bermuda components. The two continuous cotton systems were fully irrigated but tillage and low residue returns to the soil likely contributed to the lower rankings of these two systems compared to the ICLs.

The benefits of tillage for seedbed preparation and breaking up surface crusts is countered by destruction of soil aggregates and accelerated SOM decomposition which destabilizes aggregates and increases soil degradation potential (Grandy and Robertson, 2006; Grandy et al., 2006; Spohn and Giani, 2011; Yoo and Wander, 2007). While the isolated effects of tillage were beyond the scope of this study, numerous studies have identified the negative impacts of tillage on aggregate stability, SOM, and SOC content (Bronson et al., 2004; Franzluebbers and Arshad, 1996; Six et al., 2000). Tillage therefore, is posited as a driver for decreased aggregate stability in the majority of the annual vegetation components compared to the perennial vegetation components. The only exception to this trend, was R-corn which was tilled the deepest $(25 \mathrm{~cm}$ compared to 10 and $15 \mathrm{~cm}$ in cotton 1 and cotton2, respectively) and had similar mean weight diameter to the bluestem 1 and 2 components. The R-corn was a part of a fully irrigated and diverse crop rotation which would add biochemically diverse residues over multiple years. The addition of diverse crop residues have been shown to support greater SOM and SOC content (Moore et al., 2000) and in turn, would likely contribute to increased mean weight diameter. Among the annual crops, R-corn also had the highest intra-aggregate microaggregate SOC content in subsurface soils which may be the result of the combined effects of diverse residues incorporated to deeper depths. Corn and cotton stubble, both part of the R-corn rotation, can have similar degradation rates but greater polyphenols in degraded corn relative to cotton may result in greater SOC sequestration over time (Zibilske and Materon, 2005). Bluestem4, which was the youngest of the perennial components, also may have benefited from a history of diverse cropping management (cotton, corn, and wheat) prior to grassland establishment explaining the relatively high SOM, macroaggregate SOC, and intra-aggregate SOC among perennial components.

\section{Conclusions}

With the greatest overall positive impact on SOM, SOC, aggregate stability, and intra-aggregate microaggregate SOC content, FRG_RC and OWB_BER ranked above FRG_CTN, CTN_2, and CTN_1. In general, ICLs increased water stable aggregates and provided a physical protective shell for SOC via the formation of intra-aggregates within the macroaggregates. Relatively low intraaggregate microaggregate SOC in the annual crop components stemmed from increased rates of degradation and exposure of these intra-aggregate fractions due to tillage. Systems that could sustain a SOC level of at least $5.5 \mathrm{Mg} \mathrm{ha}^{-1}$, were strongly correlated with enhanced mean weight diameter, and thus aggregate stability. Although specific to these semiarid soils, this critical level can 
act as a target for producers to minimize and ultimately reverse soil degradation. As the need for sustainable resources increases, availability of arable land decreases, and levels of atmospheric $C$ increase, these diverse agroecosystems, which have been shown to be beneficial both economically and ecologically, also have the potential to reverse soil degradation in these drought prone climates and may serve as significant SOC accumulators.

\section{Disclaimer and EEO/non-discrimination statement}

Mention of trade names or commercial products in this publication is solely for the purpose of providing specific information and does not imply recommendation or endorsement by the U.S. Department of Agriculture. USDA is an equal opportunity provider and employer.

\section{Acknowledgements}

We would like to thank Paul Green for maintaining fields and Dr. Phil Brown for providing detailed management and information about the agroecosystems and operations at the Texas Tech Experimental Farm. We would like to extend our gratitude to Dr. Peter Dotray for providing access to and detailed information for the continuous cotton agroecosystem located on the Texas Tech Experimental Farm. We would like to extend thanks to Texas Alliance for Water Conservation director, Mr. Rick Kellison and Jeff Pate for providing additional information about the agroecosystems, and to the land owners for access to their commercial production sites. We would like to thank Dr. Johan Six and his students for training in the intra-aggregate fractionation method. Support for this research was provided by the USDA Southern Sustainable Agricultural Research and Education Organization (Grant \#'s L597-82 and LS10-229).

\section{References}

Acosta-Martínez, V., Bell, C.W., Morris, B.E.L., Zak, J., Allen, V.G., 2010. Long-term soil microbial community and enzyme activity responses to an integrated croppinglivestock system in semi-arid region. Agric. Ecosyst. Environ. 137, 231-240.

Acosta-Martínez, V., Zobeck, T.M., Allen, V., 2004. Soil microbial, chemical and physical properties in continuous cotton and integrated crop-livestock systems. Soil Sci. Soc. Am. J. 68, 1875-1884.

Allen, V.G., Brown, C.P., Kellison, R., Green, P., Zilverberg, C.J., Johnson, P., Weinheimer, J., Wheeler, T., Segarra, E., Acosta-Martínez, V., Zobeck, T.M., Conkwright, J.C., 2012. Integrating cotton and beef production in the Texas Southern High Plains. I. Water use and measures of productivity. Agron. J. 104, 1625-1642.

Allen, V.G., Brown, C.P., Kellison, R., Segarra, E., Wheeler, T., Dotray, P.A., Conkwright, J.C., Green, C.J., Acosta-Martínez, V., 2005. Integrating cotton and beef production to reduce water withdrawal from the Ogallala aquifer in the Southern High Plains. Agron. J. 97, 556-567.

Blanco-Canqui, H., Lal, R., 2004. Mechanisms of carbon sequestration in soil aggregates. Crit. Rev. Plant Sci. 23, 481-504.

Blanco-Canqui, H., Lal, R., 2008. Principles of Soil Conservation and Management. Springer, New York.

Bronson, K.F., Zobeck, T.M., Chua, T.T., Acosta-Martínez, V., Van Pelt, R.S., Booker, J.D., 2004. Carbon and nitrogen pools of Southern High Plains cropland and grassland soils. Soil Sci. Soc. Am. J. 68, 1695-1704.

Conant, R.T., Paustian, K., Elliott, E.T., 2001. Grassland management and conversion into grassland: effects on soil carbon. Ecol. Appl. 11, 343-355.

Daniel, J.A., Potter, K., Altom, W., Aljoe, H., Stevens, R., 2002. Long-term grazing density impacts on soil compaction. Trans. ASAE 45, 1911-1915.

Davinic, M., Fultz, L.M., Acosta-Martínez, V., Calderón, F.J., Cox, S.B., Dowd, S.E., Allen, V.G., Zak, J.C., Moore-Kucera, J., 2012. Pyrosequencing and mid-infrared spectroscopy reveal distinct aggregate stratification of soil bacterial communities and organic matter composition. Soil Biol. Biochem. 46, 63-72.

Denef, K., Zotarelli, L., Boddey, R.M., Six, J., 2007. Microaggregate-associated carbon as a diagnostic fraction for management-induced changes in soil organic carbon in two Oxisols. Soil Biol. Biochem. 39, 1165-1172.
Elliott, E.T., 1986. Aggregate structure and carbon, nitrogen, and phosphorus in native and cultivated soils. Soil Sci. Soc. Am. J. 50, 627-633.

Elliott, E.T., Palm, C.A., Reuss, D.E., Monz, C.A., 1991. Organic matter contained in soil aggregates from a tropical chronosequence: correction for sand and light fraction. Agric. Ecosyst. Environ. 34, 443-451.

Franzluebbers, A.J., Arshad, M.A., 1996. Water-stable aggregation and organic matter in four soils under conventional and zero tillage. Can. J. Soil Sci. 76, $387-$ 393.

Franzluebbers, A.J., Stuedemann, J.A., 2008. Early response of soil organic fractions to tillage and integrated crop-livestock production. Soil Sci. Soc. Am. J. 72, 613-625.

Fultz, L.M., Moore-Kucera, J., Zobeck, T.M., Acosta-Martínez, V., Allen, V.G., 2013. Soil aggregate-carbon pools after 13 years under a semi-arid integrated crop-livestock agroecosystem. Soil Sci. Soc. Am. J. 77, 1659-1666, http://dx.doi.org/10.2136/sssaj2012.0423.

Gale, W.J., Cambardella, C.A., 2000. Carbon dynamics of surface residue-and rootderived organic matter under simulated no-till. Soil Sci. Soc. Am J. 64, 190-195.

Grandy, A.S., Loecke, T.D., Parr, S., Robertson, G.P., 2006. Long-term trends in nitrous oxide emissions, soil nitrogen, and crop yields of till and no-till cropping systems. J. Environ. Qual. 35, 1487-1495.

Grandy, A.S., Robertson, G.P., 2006. Aggregation and organic matter protection following tillage of a previously uncultivated soil. Soil Sci. Soc. Am. J. 70, 1398-1406.

Jagadamma, S., Lal, R., 2010. Distribution of organic carbon in physical fractions of soils as affected by agricultural management. Biol. Fertil. Soils 46, $543-$ 554.

Kettler, T.A., Doran, J.W., Gilbert, T.L., 2001. Simplified method for soil particlesize determination to accompany soil-quality analysis. Soil Sci. Soc. Am. J. 65, 849-852.

Kong, A.Y.Y., Six, J., Bryant, D.C., Denison, R.F., van Kessel, C., 2005. The relationship between carbon input, aggregation, and soil organic carbon stabilization in sustainable cropping systems. Soil Sci. Soc. Am. J. 69, 1078-1085.

Lichter, K., Govaerts, B., Six, J., Sayre, K.D., Deckers, J., Dendooven, L., 2008. Aggregation and $\mathrm{C}$ and $\mathrm{N}$ contents of soil organic matter fractions in a permanent raised-bed planting system of the highlands of Central Mexico. Plant Soil 305 237-252.

Lorenz, N., Dick, R.P., 2011. Sampling and pre-treatment of soil before enzyme analysis. In: Dick, R.P. (Ed.), Methods of Soil Enzymology. Soil Science Society of America, Wisconsin, pp. 85-101

Moore, J.M., Klose, S., Tabatabai, M.A., 2000. Soil microbial biomass carbon and nitrogen as affected by cropping systems. Biol. Fert. Soils 31, 200-210.

N.O.A.A. [National Oceanic Atmospheric Administration], 2012. Lubbock precipitation from 1911 to present, Available at: http://www.srh.noaa.gov/ lub/?n=climate-klbb-pcpn (accessed 05.05.13).

Olchin, G.P., Ogle, S., Frey, S.D., Filley, T.R., Paustian, K., Six, J., 2008. Residue carbon stabilization in soil aggregates of no-till and tillage management of dryland cropping systems. Soil Sci. Soc. Am. J. 72, 507-513.

Potter, K.N., Jones, O.R., Torbert, H.A., Unger, P.W., 1997. Crop rotation and tillage effects on organic carbon sequestration in the semiarid southern great plains. Soil Sci. 162, 140-147.

S.A.S. Institute, 2008. The SAS System for Windows Version 9.2. SAS Inst., Cary, NC.

Simpson, R.T., Frey, S.D., Six, J., Thiet, R.K., 2004. Preferential accumulation of microbial carbon in aggregate structures of no-tillage soils. Soil Sci. Soc. Am. J. 68 1249-1255.

Six, J., Elliott, E.T., Paustian, K., 2000. Soil macroaggregate turnover and microaggregate formation, a mechanism for $C$ sequestration under no-tillage agriculture. Soil Biol. Biochem. 32, 2099-2103.

Spohn, M., Giani, L., 2011. Impacts of land use change on soil aggregation and aggregate stabilizing compounds as dependent on time. Soil Biol. Biochem. 43, 1081-1088.

Texas Alliance for Water Conservation (TAWC), http://www.depts.ttu.edu tawc/ResearchSummaries/Year_7_FinalAnnualReport\%20pdf.pdf (accessed 05.11.13) 2012. Report on an integrated approach to water conservation for agriculture in the Texas Southern High Plains.

Texas E.T. Network, Available at: http://texaset.tamu.edu/pet.php (accessed 08.08.13) 2013. Average Monthly ETo (PET).

van Bavel, C.H.M., 1950. Mean weight-diameter of soil aggregates as a statistica index of aggregation. Soil Sci. Soc. Am. Proc. 14, 20-23.

Wester, D.B., 1992. Viewpoint: Replication, randomization, and statistics in range research. J. Range Manage. 45, 285-290.

Yoo, G., Wander, M.W., 2007. Tillage effects on aggregate turnover and sequestration of particulate and humified soil organic carbon. Soil Sci. Soc. Am. J. 72, 670-676.

Yoo, G., Yang, X., Wander, M.M., 2011. Influence of soil aggregation on SOC sequestration: a preliminary model of SOC protection by aggregate dynamics. Ecol. Eng. 37, 487-495

Zibilske, L.M., Materon, L.A., 2005. Biochemical properties of decomposing cotton and corn stem and root residues. Soil Sci. Soc. Am. J. 69, 378-386.

Zilverberg, C., 2012. Agroecology of three integrated crop-livestock systems in the Texas High Plains. Texas Tech University, Retrieved from http://library.ttu.edu/etd (Doctoral Dissertation). 